\title{
THE ENERGY EFFICIENCY GAP IN TURKISH MARITIME TRANSPORTATION
}

\author{
Olgun Konur \\ Murat Bayraktar \\ Murat Pamik \\ Barış Kuleyin \\ Mustafa Nuran \\ Dokuz Eylul University, Izmir, TURKEY
}

\begin{abstract}
The Turkish Merchant Shipping Industry has recently witnessed an increasing awareness of the importance to minimize environmental pollution and fuel oil consumption. Together with certain non-governmental organizations and media concerns about environmental protection, the International Maritime Organization (IMO) has been strict on controlling undesirable effects on the environment and, consequently, forcing shipping companies to minimize their emissions. Besides, today's highly advanced technology companies over the world have developed various innovative systems that can be utilized to minimize carbon emission, thus giving assurance to relevant investors that their investments are most likely to turn out well with a considerable financial gain in the short or long term. Despite all such favorable developments, in a general look, shipping companies seem reluctant in making use of technologies providing efficiency in energy consumption. This reluctance has eventually brought about the term "Energy Efficiency Gap". This research conducts a questionnaire, created by Acciaro et al. [1], among the shipping companies in Turkey. 20 respondent companies, who represent 26 percent of the Turkish owned merchant marine fleet of over 1000 gross tonnage in terms of deadweight cargo capacity, participated in the research. The Pearson correlation analysis was used, and interpretations were made according to the obtained statistical values. The aim of the research was to identify reasons and points restraining the use of new technologies regarding energy efficiency, as well as to develop proposals for the innovators in this field about how to overcome this handicap concerning technical and managerial aspects of gaining energy efficiency.
\end{abstract}

Keywords: Energy efficiency gap; Maritime transportation; Energy efficiency technologies; Carbon emission

\section{INTRODUCTION}

The onset of environmental problems in the world has prompted authorities to take preventive actions to reduce ship-borne exhaust emissions. As a result of both these actions, and growing economic concerns of the maritime industry, the energy efficiency improving applications have become of great importance in ships in recent years.

IMO has made a quick response to the environmental protection calls. They conducted various studies to reduce the ship-based emissions and started to regulate the ship transportation industry by implementing new rules. The Regulations for the Prevention of Air Pollution from Ships were added to the Annex VI Convention with the 1997 protocol by amending the MARPOL 73/78 Convention. These regulations entered into force on May 19, 2005. The MARPOL Annex VI regulates the arrangements made to limit the ozone layer by depleting ship emissions of nitrogen oxides $\left(\mathrm{NO}_{\mathrm{x}}\right)$ and sulphur oxides $\left(\mathrm{SO}_{\mathrm{x}}\right)$ in exhaust gases [33] In 2009, IMO published the Second IMO Greenhouse Gas Study which revealed that the ship-based $\mathrm{CO}_{2}$ emissions were projected to increase significantly in the coming decades. Depending on future economic and energy developments, the analyzed scenarios projected an emission increase by $50 \%$ to $250 \%$ in the period to 2050 [6]. Further actions with additional regulations on efficiency and emissions could 
mitigate the emissions growth. Therefore, applications of the Energy Efficiency Design Index (EEDI) and the Ship Energy Efficiency Management Plan (SEEMP) were accepted in July 2011. EEDI was made mandatory by the Marine Environment Protection Committee (MEPC) for new ships and SEEMP for all ships [19, 30].

There has to be a SEEMP plan specifically prepared for vessels [18]. In spite of these preventive actions, new projections still show an increase in some greenhouse gas emissions, considering the increasing demand for fossil fuels. As a result of Tier III and Tier IV engines entering the world fleet, the emissions of nitrogen oxides increase at a lower rate than $\mathrm{CO}_{2}$ emissions. The emissions of particulate matters show an absolute decrease until 2020, and sulphurous oxides continue to decline through to 2050, mainly because of MARPOL Annex VI requirements imposed on the sulphur content of fuels [17].

The policymakers' initiation to reduce the global warming potential from ship-based emissions has become an inevitable cause of innovation acceleration in this field [32]. The international regulations in force give limited time to the maritime transportation industry to adopt the requirements [40]. Both the engine suppliers, and other parties related to the emission reduction technologies are still studying hard to innovate products satisfying the goals of the above-mentioned Annex VI amendments. All in all, the emergence of new and modified emission reduction technologies in recent few years, and also energy efficiency improving technologies, has been a great challenge for the maritime transport industry.

Reducing fuel costs via using eco-friendly applications is another point of view for the sustainability of these innovations. As the cost-effectiveness potential of the emission reduction technologies grows with time [11], the feasibility of the products affects the willingness of more shipping companies to use them in their fleet. However, in practice, the implementation of economically viable technologies to marine vessels is going slower than expected in the worldwide market because of some "barriers to energy efficiency", as defined in the literature [1]. The energy efficiency gap [23] is another term which defines barriers to energy efficiency. According to Klemick and Wolverton [26], the energy efficiency gap is defined as the difference between the amount of energy that is currently consumed and the amount that should be consumed, relative to some notion of the optimal level. In the shipping industry, innovative products that provide energy efficiency with cost efficiency are developing very fast in recent years. This situation creates an expanding energy efficiency gap on marine vessels because of some barriers to the implementation of energy efficient end-products [41].

\section{LITERATURE REVIEW}

Considering the current and oncoming IMO legislations, the technologies reducing emission and improving energy efficiency in the field of marine transportation systems have been enhanced significantly. Bedford et al. [3] described a direct water injection system that is operated by injecting water into the combustion chamber via a separate nozzle from the fuel to reduce $\mathrm{NO}_{\mathrm{x}}$ emissions by $50-60 \%$ under high loads and eliminate harmful effects of bad combustion $[8,45]$. As explained in the study by Kristensen [26], the operating principle of the exhaust gas recirculation system (EGR) is to recirculate some of the engine exhaust gas back to the engine. The mixing of the exhaust gas with the intake air increases the specific heat of the intake mixture, which leads to a reduction in the ignition temperature and reduces the oxygen concentration in the combustion chamber. A significant reduction is observed in the number of nitrogen oxides produced due to the combustion temperature decrease. The EGR system allows approximately $20 \%$ reduction of $\mathrm{NO}_{\mathrm{x}}$ emissions. The Selective Catalytic Reduction (SCR) process chemically transforms the $\mathrm{NO}_{\mathrm{x}}$ molecule into molecular nitrogen and water vapor. A nitrogen-based reagent, such as ammonia or urea, is injected into the exhaust gas in the exhaust line. The hot flue gas and the reagent are passed through a catalyst. The reactant emitted by the catalyst selectively reacts with $\mathrm{NO}_{x}$ at a certain temperature range and in the presence of the catalyst and oxygen.

The global fuel fleet consumes approximately 330 million tons of fuel annually. Approximately, $80-85 \%$ of these consumed fuels contain sulphur. At present, liquefied natural gas (LNG), liquid petroleum gas (LPG), electric energy, solar power, biodiesel, and methanol are at the top of alternative fuels used in the maritime industry [7]. In terms of environmental emissions, the use of LNG as fuel plays an important role as an emission reducer, with the ratios of $\mathrm{CO}_{2}$ emissions up to $20 \%$, sulphur oxides $\left(\mathrm{SO}_{\mathrm{x}}\right)$ up to $100 \%$, Nitrogen oxides $\left(\mathrm{NO}_{\mathrm{x}}\right)$ up to $90 \%$, and particulate matter (PM) up to $99 \%$ [20]. LNG will be an alternative fuel that meets stringent ECA requirements because it emits small quantities of $\mathrm{NO}_{\mathrm{x}}$ [47]. Considering the environment-friendly feature of LNG, propulsion of LNG fueled ships comes to an important point [5]. Also, the cost of liquefying natural gas is almost the same compared to IFO 380, according to the data taken at February 2019[10, 46].

The solar energy technology transforms solar energy into electricity and thermal energy. Every square meter of the earth's surface draws about 1000 Watts of energy from the sun [13]. Solar energy provides a clean, environment-friendly, and non-consumable source of energy for humanity. The cost of energy acquired from the sun is also falling steadily due to the competition in this market [16]. Although there are significant advantages offered by solar energy, it is necessary to keep in mind some defects while utilizing this energy source [14]. Wind energy technologies convert the mechanical energy into electrical energy by taking advantage of the kinetic energy of the wind. The kinetic energy of the airflow drives the wind turbine blades and the drive shaft, thus providing mechanical energy to the wind turbine generator [21]. Furthermore, there are some other technologies that utilize wind forces to assist the propulsion of ships. One of them is wind kites that use kite power for ship propulsion. Another option is the wing sails that consist of different types of sails or wings. The Flettner 
rotor technology, which uses the Magnus effect to provide the ship with harnessing wind energy, has been started to develop in recent years [29].

Hull cleaning is a method that leads to a significant reduction in daily fuel consumption, as well as to increasing the energy efficiency of vessels in a very cost- effective way [2].

Waste heat recovery systems have gained great significance for ship owners in the last decade, following their many landbased applications [28]. Thermoelectric generators seem suitable for small scale commercial applications. On the other hand, large-scale applications, such as ships, require Rankine-based systems which can potentially offer greater environmental gains and better energy efficiency than thermoelectric generators [25].

Most of the literature studies refer to the energy efficiency gap in the industrial sectors such as textile [44], household [38], paper [42], ceramics [31], and construction [15] industries. Financial matters related with investing into energy efficiency are also discussed in several studies $[4,9,34,36,43]$.

There are limited studies in the literature which concern the energy efficiency gap issue for marine transportation systems. SEEMP and EEDI regulations seem to have an inspiring role for both academic and institutional studies. Jafarzadeh and Utne [22] propose a framework for overcoming barriers to the energy efficiency in the shipping industry. The framework is designed in 5 steps, and starts with identifying the barriers and categorizing them. The categorized barriers are analyzed and ranked by any suitable multi-criteria decision making (MCDM) methods in step 2. Possible measures for overcoming the identified barriers are assigned. Then, interactions between the barriers are identified in step 3 and 4 . Step 5 is about documentation of the results, with a feedback loop due to possible reductions in the previous barriers.

Poulsen and Sornn-Friese [37] have studied the influence of the third-party ship management to energy efficiency. Lack of information on energy efficiency, lack of energy training, and lack of time to produce and provide reliable energy efficiency information are highlighted as barriers to ship operations with third- party ship management.

Barriers to improving the energy efficiency in short sea shipping are discussed by Johnson et al. [24] in their action research designed case study. The collaboration of two shipping companies for implementing an energy management system to their fleet is examined with active participation of researchers to the implementation process. Discussions and results are mainly focused on what best practices could be in an energy management plan when considering the SEEMP requirements. Another outcome derived from that case study was the understanding of barriers which may hinder the companies in achieving energy efficient operations.

Fridell et al. [12] describe several parameters to improve the energy efficiency in shipping by exemplifying the Latin American and Caribbean regions. Barriers to energy efficiency between different modes of transport in these regions are well defined. Uncertainties about the future fuel cost, high rate of technological risks, stakeholder influences, ship ownercharterer agreements, low second-hand values, and the lack of capital stock within shipping companies have been seen as the major factors affecting the implementation of energyefficient technologies. Also, the shore-side electricity (cold ironing) method has been seen as a good option to reduce the emissions in populated coastal areas.

Rehmatullaa et al. [39] conducted a survey with the participation of 200 shipping companies, mostly from Europe. The implementation of over 30 energy efficiency and $\mathrm{CO}_{2}$ emission reduction technologies were surveyed. The study shows that the companies tend to implement technologies which offer energy efficiency gains. This tendency indicates an equal distribution among the design, hydrodynamic, and machinery measures by selecting only a number of different measures in each category. Small energy efficiency gains at the ship level, when accompanied with low initial costs and high payback rate, are the motivations for most of the implementation choices.

The study of Acciaro et al. [1] provides a good understanding of relevant barriers to the implementation of energy efficiency improving technologies among the Norwegian Ship-owners' Association members. A newly developed questionnaire, which was verified by DNV GL experts and the representatives of the Norwegian Shipowners' Association, was utilized to gain a better understanding of barriers to the implementation of new technologies among Norwegian shipping companies. $12 \mathrm{CO}_{2}$ abatement technologies were taken into account in the study. A set of barriers to the shipping industry related energy efficiency were defined as a result of interviews with DNV experts and shipping companies, and an intensive literature review. These barriers are categorized as: safety and reliability, technical uncertainty, behavioural barriers, market constraints, financial and economic constraints, and complexity. As a result of the study, operational measures appear to have lower barriers than hardware measures. Immature technologies also show higher barrier levels. An active role of the policy maker through financial incentives and revision of existing regulation is suggested to be effective in overcoming these barriers.

\section{METHODOLOGY}

This study aims to assess the energy efficiency gap in Turkish maritime transportation by conducting the questionnaire created by Acciaro et al. [1] among 20 different shipping companies representing 26 percent of the Turkish merchant marine fleet of over 1000 gross tonnage in terms of deadweight cargo capacity. The responses have been received from the employees carrying on the duties of ship owner, general manager, technical manager, inspector, designated person ashore (DPA), human resources manager, master, and engineer in pioneer companies of the Turkish merchant marine fleet, as can be seen from the demographic structure of participants in Fig. 1. 


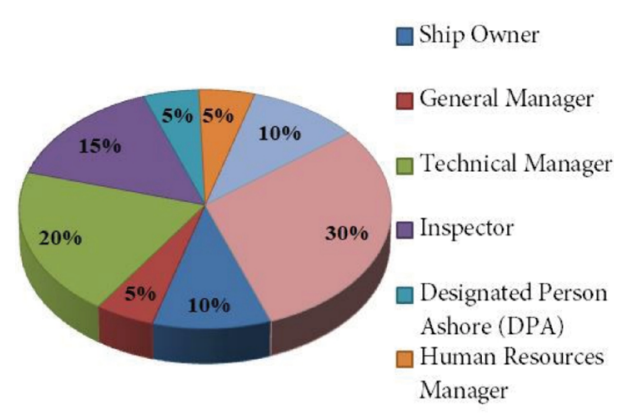

Fig. 1. Hierarchical distribution of survey participants

Among the most effective and widely used techniques, the Pearson's correlation analysis was applied to establish the framework for barriers to emission reducing and energy efficiency improving technologies. The correlation analysis is a statistical method used to test the relationship between two variables or the relationship of one variable with two or more variables. The purpose of the correlation analysis is to see how the dependent variable (y) changes when the independent variable (x) changes. In order to perform the analysis, both variables must be continuous and have normal distribution. The result of the correlation analysis shows whether there is a linear relationship between the variables or not (See Tab. 1). In the former case, the correlation coefficient is calculated from this relation [35].

Tab. 1. Intervals of correlation coefficient $R$ [35]

\begin{tabular}{|c|c|}
\hline R Values & Comments \\
\hline $0,00-0,25$ & Very Poor \\
\hline $0.26-0.49$ & Poor \\
\hline $0,50-0,69$ & Medium \\
\hline $0.70-0.89$ & High \\
\hline $0.90-1.00$ & Too High \\
\hline
\end{tabular}

The emission reducing and energy efficiency improving technologies are described in Tab. 2, together with their abbreviations used when discussing the results in Section 4.

Tab. 2. Emission reducing and energy efficiency improving technologies

\begin{tabular}{|c|c|c|}
\hline $\begin{array}{l}\text { Technology } \\
\text { Description }\end{array}$ & Description & Abbreviation \\
\hline Speed reduction & $\begin{array}{l}\text { More efficient speed for } \\
\text { operation }\end{array}$ & SR \\
\hline Voyage performance & $\begin{array}{l}\text { Route determination based } \\
\text { on weather conditions and } \\
\text { trim, draft control etc. } \\
\text { systems to improve operation } \\
\text { performance } \\
\end{array}$ & $\mathrm{VP}$ \\
\hline $\begin{array}{l}\text { Friction reducing } \\
\text { technologies }\end{array}$ & Ship resistance reduction & FRT \\
\hline $\begin{array}{l}\text { Propeller enhancing } \\
\text { devices }\end{array}$ & $\begin{array}{l}\text { Increasing efficiency by } \\
\text { taking advantage of propeller } \\
\text { characteristics }\end{array}$ & $\mathrm{PE}$ \\
\hline $\begin{array}{l}\text { Electrical connection } \\
\text { from the shore }\end{array}$ & $\begin{array}{l}\text { Connecting shore electricity to } \\
\text { the ship in ports }\end{array}$ & EC \\
\hline $\begin{array}{l}\text { Reducing the need } \\
\text { for auxiliary power }\end{array}$ & $\begin{array}{l}\text { Reduction of needed power } \\
\text { such as light, heat and electric } \\
\text { motor }\end{array}$ & $\mathrm{RN}$ \\
\hline
\end{tabular}

\begin{tabular}{|l|l|c|}
\hline $\begin{array}{l}\text { Technology } \\
\text { Description }\end{array}$ & \multicolumn{1}{|c|}{ Description } & Abbreviation \\
\hline Waste heat recovery & $\begin{array}{l}\text { Systems that can recover part } \\
\text { of exhaust gas heat energy }\end{array}$ & DME \\
\hline $\begin{array}{l}\text { Development of the } \\
\text { main engine }\end{array}$ & $\begin{array}{l}\text { Main engine control and } \\
\text { efficiency improvement }\end{array}$ & SE \\
\hline Solar energy & $\begin{array}{l}\text { Utilizing solar energy for } \\
\text { electricity generation }\end{array}$ & LNG \\
\hline $\begin{array}{l}\text { LNG (Liquefied } \\
\text { natural gas) }\end{array}$ & $\begin{array}{l}\text { Using gas fuels instead of } \\
\text { diesel-based fuels }\end{array}$ & WP \\
\hline Wind energy & $\begin{array}{l}\text { Using wind power for } \\
\text { electricity generation on the } \\
\text { vessel }\end{array}$ & $\begin{array}{l}\text { Energy production from } \\
\text { natural gas or other hydrogen- } \\
\text { containing gases }\end{array}$ \\
\hline Fuel cell & FC \\
\hline
\end{tabular}

Barriers to the implementation of new technologies for exhaust emissions have been addressed to the participants to determine the level of these barriers (see Tab. 3).

Tab. 3. Barriers to the implementation of new technologies

\begin{tabular}{|l|l|}
\hline Level of knowledge & Safety issue for the crew and ship \\
\hline Purchase and installation costs & $\begin{array}{l}\text { Reliability issue for the crew and } \\
\text { ship }\end{array}$ \\
\hline $\begin{array}{l}\text { Effectiveness in reducing exhaust } \\
\text { emissions }\end{array}$ & $\begin{array}{l}\text { Degree of compliance with } \\
\text { current regulations }\end{array}$ \\
\hline Ease of initial installation & $\begin{array}{l}\text { Ease of implementation to ship } \\
\text { considering the charter agreement }\end{array}$ \\
\hline Ease of use & Suitability to the company \\
\hline Level of their technical maturity & \\
\hline
\end{tabular}

The conditions affecting these issues have been expressed in eleven headings. The statements related to the implementation of new technologies aiming at reducing exhaust emissions are shown in Tab. 4. The barriers to the implementation of new technologies shown in Tab. 5 have been surveyed according to their significance levels to get the effective results about the research question.

Tab. 4. Statements related to the implementation of new technologies aiming at reducing exhaust emissions in the participant's shipping company

\begin{tabular}{|l|c|}
\hline Installation costs are very expensive & IC \\
\hline Operating costs are too high & OC \\
\hline There are a lot of uncertainties with respect to their costs & UC \\
\hline The initial installation is very difficult & IID \\
\hline It is very difficult to use & DU \\
\hline $\begin{array}{l}\text { There are a lot of uncertainties with respect to their } \\
\text { effectiveness }\end{array}$ & UE \\
\hline Safety risk of the ship increases with their utilization & SR \\
\hline The know-how about the new technologies is not reliable & TR \\
\hline $\begin{array}{l}\text { The company has not reached the capacity to afford new } \\
\text { technologies }\end{array}$ & CC \\
\hline Charter agreements restrain the use of these technologies & CH \\
\hline
\end{tabular}

Tab. 5. Barriers to new technologies that indicate significance levels

\begin{tabular}{|l|c|}
\hline Complexity of operation & CO \\
\hline Operating costs & OC \\
\hline Technical maturity & TM \\
\hline Current regulations & CR \\
\hline Complexity of initial installation & CII \\
\hline
\end{tabular}




\begin{tabular}{|l|c|}
\hline Integration difficulties in the system & IDS \\
\hline Technical data & TD \\
\hline Lack of information & LOI \\
\hline Charter agreements & CA \\
\hline Organizational maturity & OM \\
\hline Safety & S \\
\hline Lack of awareness & LOA \\
\hline Installation cost & IC \\
\hline Access to capital & AC \\
\hline Lack of incentives & LI \\
\hline Reliability & R \\
\hline
\end{tabular}

that the shipping companies are confident with their crew to operate these technologies with proper familiarization. The companies that provide the emission reducing devices also appear to be trusted by the shipping companies in the context of the ability to install the products with professional workmanship and in a time-effective manner.

The participants mostly agree on high cost of initial installation (See Fig. 3). The uncertainties with respect to the cost of new technologies are another strong factor to be considered seriously. On the other hand, these technologies are assessed to be easily operated systems according to multiple point of views.

The correlation analysis presents the strongest relationship between the operating cost (OC) and the installation cost (IC), as expressed in Table 6 . Besides, the operating cost (OC) has significant relation with the complexity of operation (CO). No connection has been established between these and other barriers. These relations state that the shipping companies agree on that the technologies are both costly and complex

According to the data obtained from the questionnaires, the importance levels of barriers to the implementation of new technologies are illustrated in Fig. 2. systems to implement and operate.

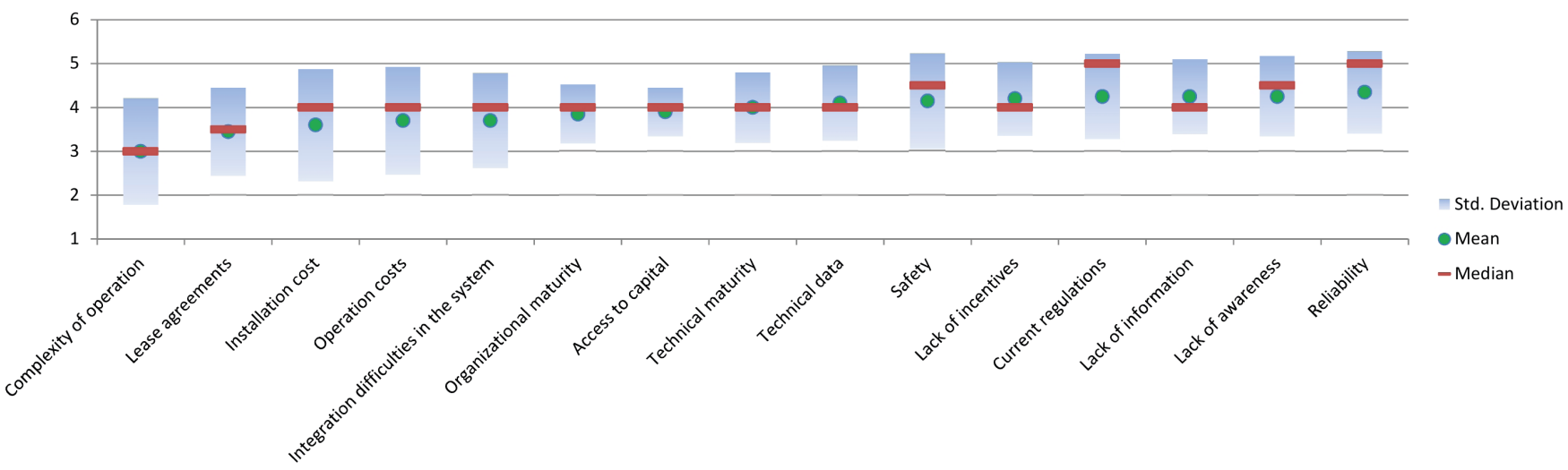

Fig. 2. Importance levels of emission reducing and energy efficiency improving technology barriers

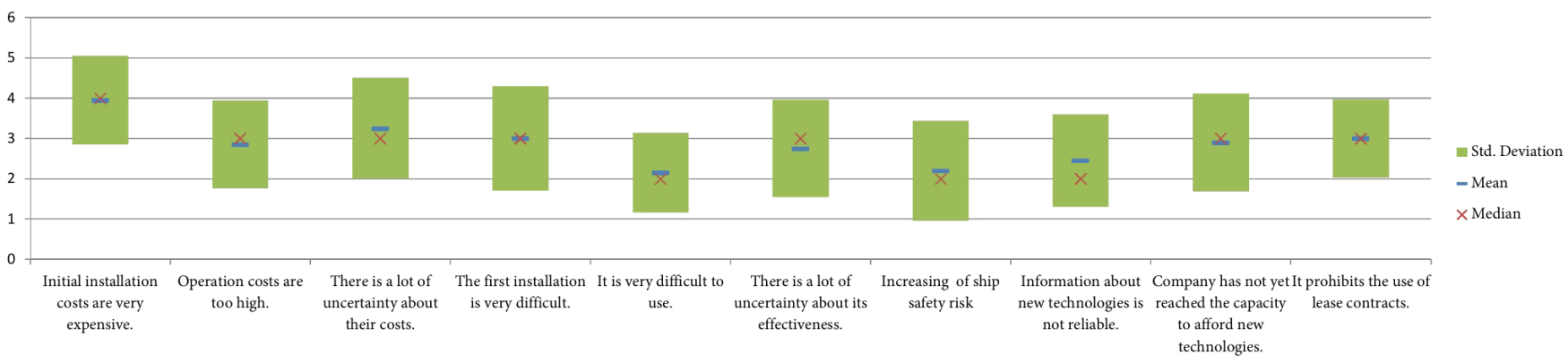

Fig. 3. Agreement levels to the statements related to new technologies aiming at reducing the exhaust emissions

Reliability, lack of awareness, lack of information, and current regulations are observed as the most critical points considering the willingness of the companies to implement these technologies. The remaining measures also show a close importance level. Only the complexity of operation and the initial installation stage have a lower significance level compared to other barriers. This situation can be interpreted

Tab. 6. Pearson correlation coefficients of selected barriers to the implementation of new technologies

\begin{tabular}{|c|c|c|c|}
\hline & OC & CO & IC \\
\hline OC & & $0,68^{* *}$ & $0,94^{* *}$ \\
\hline CO & $0,68^{* *}$ & & $0,75^{* *}$ \\
\hline IC & $0,94^{* *}$ & $0,75^{* *}$ & \\
\hline
\end{tabular}

**. Correlation is significant at the 0.01 level (2-tailed). 
The results shown in Tab. 7 illustrate that the technological advancement in the field of emission reduction and energy efficiency improvement has failed to provide a reliable source of know-how according to the shipping companies' point of view. The correlation factor of 0.822 between SR and TR in the same table shows that the safety and reliability issues are highly related with each other, and that the insufficient know-how has raised concern about the increased risk to ship's safety.

Tab. 7. Pearson correlation coefficients of agreement levels to the statements related to new technologies aiming at reducing exhaust emissions

\begin{tabular}{|c|c|c|c|c|}
\hline & SR & TR & UC & DU \\
\hline SR & & $0,822^{* *}$ & - & $0,533^{*}$ \\
\hline TR & $0,822^{* *}$ & & - & - \\
\hline UC & - & - & & $0,564^{* *}$ \\
\hline DU & $0,533^{*}$ & - & $0,564^{* *}$ & \\
\hline
\end{tabular}

**. Correlation is significant at the 0.01 level (2-tailed)

*. Correlation is significant at the 0.05 level (2-tailed)

Figure 4 compares the average barrier levels of the technologies to their suitability to the company and the familiarity of the companies to the technologies. Fuel cell (FC), wind power (WP), LNG, and solar power (SP) technologies possess the highest barrier levels, respectively.

\section{CONCLUSION}

The paper evaluates barriers to the implementation of new technologies which aim at reducing exhaust emissions and improving energy efficiency in the Turkish maritime transportation industry. This evaluation bases on the questionnaire created by Acciaro et al. [1], and its results are discussed.

Reliability is deduced as the most important barrier against the implementation of the emission reducing and energy efficiency improving technologies to the Turkish merchant marine fleet. The most significant relationship among the barriers is found between the operating cost and the installation cost, with the $\mathrm{R}$ value of 0.937 .

As expected, the costs are generally the main topic, but also the uncertainties about operational measures and payback periods make it difficult to convince the shipping companies to utilize innovative products of the emission reduction technology. The shipping companies regard the operational measures as more suitable to the company, as these measures require lower initial and operational costs. The know-hows about these technologies are considered as insufficient and unreliable, which raises concern about the increased risk to ship's safety. Therefore, reliable information must be provided, and the risk status concerning the safety of operations must be eliminated to increase the application density of the technologies by the shipping companies.

Familirty to the Technologies - Average Barrier Level - Suitability to the Company

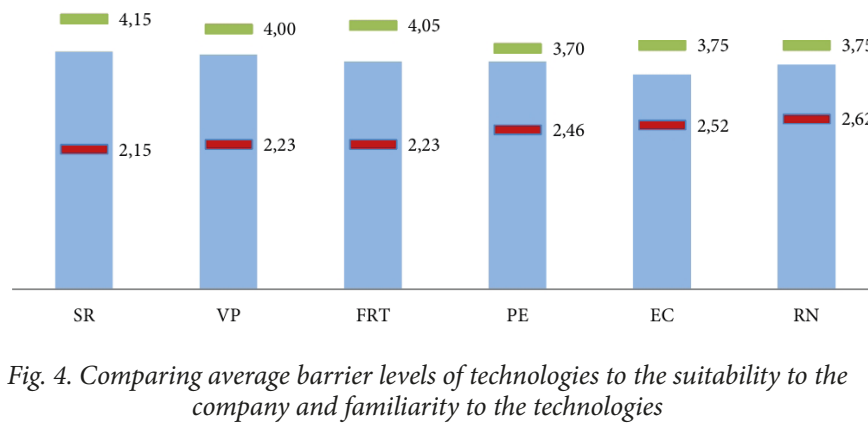

These technologies are also indicated as unsuitable to be applied. Speed reduction (SR), friction reducing technologies (FRT), and voyage performance (VP) have been found most appropriate applications for the companies due to the requirements of considerably lower cost and complexity than other innovations. In this context, the companies look reluctant to utilize costly and complex applications related to emission reduction and energy efficiency improvement, as well. The participating companies generally score just above the average in terms of technology familiarity, which reveals that more cooperation needs to be developed between the academicians, policy makers, technology developers, and end-users.

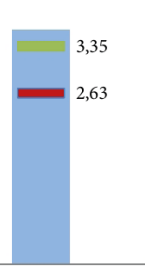

WH

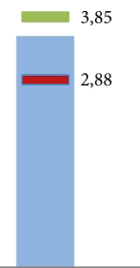

DME

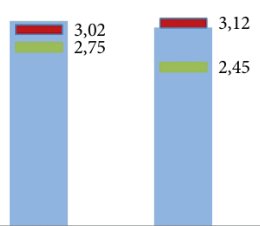

LNG

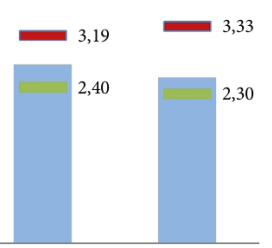

WP

FC
The study of Acciaro et al. [1] aimed to find the barriers in the Norwegian shipping industry. As a result of the study, operational measures appeared to have lower barriers than hardware measures. The same pattern is observed among the Turkish shipping companies. Renewable energy and LNG technologies have the highest barrier scores for both countries. Maturity levels of the technologies and cost considerations have possessed a high barrier level. An active role of Norwegian policymakers through financial incentives has also been suggested. In comparison, the Turkish maritime transportation is basically in the need to revise the existing regulations to be effective, along with incentives, in overcoming these barriers. The reliability and safety issues are among the most important issues for both countries.

In this respect, it is suggested that the university-industry cooperation should be well-established in the emission reduction and energy efficiency improvement technology fields to accelerate the innovative products with reliable source 
of information. In that way, the payback periods and the initial costs may be decreased as a solution to the main concern of end-users, and the energy efficiency gap would be narrowed in the Turkish maritime transportation industry.

\section{ACKNOWLEDGEMENTS}

We want to express our sincere thanks to Acciaro, Hoffmann, and Eide for their support in providing us with the questionnaire they have developed. We also acknowledge the shipping companies who have participated in the survey and considered this research as an enlightening guide to the energy efficiency gap problem of Turkish maritime transportation.

\section{REFERENCES}

1. Acciaro, M., Hoffmann, P.N., Eide, M.S., 2013. The energy efficiency gap in maritime transport. Journal of Shipping and Ocean Engineering. 3(2013), 1-10.

2. Adland, R., Cariou, P., Jia, H., Wolff, F.C., 2018. The energy efficiency effects of periodic ship hull cleaning. J. Clean. Prod. 178, 1-13. https://doi.org/10.1016/j.jclepro.2017.12.247.

3. Bedford, F., Rutland, C., Dittrich, P., Raab, A., Wirbeleit, F., 2000. Effects of direct water injection on DI diesel engine combustion. No. 2000-01-2938. SAE Technical Paper.

4. Bergmann, A., Rotzek, J.N., Wetzel, M., Guenther, E., 2017. Hang the low-hanging fruit even lower - evidence that energy efficiency matters for corporate financial performance. Journal of Cleaner Production 147(2017), 66-74. http://dx.doi.org/10.1016/j.jclepro.2017.01.074.

5. Boylston,J.W.,2011.LNGasafuel for vessels somedesign notes. http://leg.wa.gov/JTC/Documents/Studies/LNG/ LNGFuelDesignNotes_060911.pdf. (Accessed 20 October 2017)

6. Buhaug, O., Corbett, J.J., Eyring, V., Endresen, O., Faber, J., Hanayama, S., Lee, D.S., Lee, D., Lindstad, H., Markowska, A.Z., Mjelde, A., Nelissen, D., Nilsen, J., Palsson, C., Wanquing, W., Winebrake, J.J., Yoshida, K., 2009. Prevention of air pollution from ships - Second IMO GHG Study. MEPC 59/INF.10. International Maritime Organization, London, UK.

7. Chryssakis, C., Balland, O., Tvete, H.A., Brandsæter, A., 2014. Alternative fuels for shipping chain. Position paper: 17-2014. https://transportemaritimoglobal.files.wordpress. com/2014/01/dnv-gl-alternative-fuel-2014-positionpaper. pdf. (Accessed 09 November 2017)

8. Deal, A.L., 2013. Liquefied natural gas as a marine fuel. NEPI Working Paper. http://www.glmri.org/downloads/lngMisc/NEPI\%20
LNG\%20as\%20a\%20Marine\%20Fuel\%205-7-13.pdf. (Accessed 18 October 2017)

9. DeCanio, S.J., Watkins, W.E., 1998. Investment in energy efficiency: do the characteristics of firms matter? The review of economics and statistics. 80(1), 95-107. http://dx.doi.org/10.1162/003465398557366.

10. DNV GL, 2019. Current price development oil and gas. https://www.dnvgl.com/maritime/lng/current-pricedevelopment-oil-and-gas.html. (Accessed 12 March 2019)

11. Eide, M.S., Longva, T., Hoffmann, P., Endresen Ø., Dalsøren, S.B., 2011. Future cost scenarios for reduction of ship CO2 emissions. Maritime Policy \& Management, 38(1), 11-37. https://doi.org/10.1080/03088839.2010.533711.

12. Fridell, E., Winnes, H., Styhre, L., 2013. Measures to improve energy efficiency in shipping. FAL Bulletin, 324(8). http://www.transportportal.se/energieffektivitet/ measures\%20to\%20improve\%20energy\%20efficiency\%20 in\%20shipping.pdf. (Accessed 09 May 2017)

13. Genesis Energy, 2010. Solar energy. http://www.electrocity. co.nz/images/factsheets/solar\%20energy.pdf. (Accessed 12 November 2017)

14. Gromicko, N., 2012. Disadvantages of Solar Energy. https:// www.nachi.org/disadvantages-solar-energy.htm. (Accessed 12 November 2017)

15. Gupta, P., Anand, S., Gupta, H., 2017. Developing a roadmap to overcome barriers to energy efficiency in buildings using best worst method. Sustainable Cities and Society, 31(2017), 244-259. http://dx.doi.org/10.1016/j.scs.2017.02.005.

16. Hoeven, V.D.M., 2011. Solar energy perspectives. https://www.iea.org/publications/freepublications/ publication/solar_energy_perspectives2011.pdf. (Accessed 12 November 2017)

17. IMO, 2014. Third IMO GHG study 2014: executive summary and final report. http://www.imo.org/en/OurWork/Environment/ PollutionPrevention/AirPollution/Documents/Third\%20 Greenhouse\%20Gas\%20Study/GHG3\%20Executive\%20 Summary\%20and\%20Report.pdf. (Accessed 15 October 2017)

18. IMO, 2017. MARPOL73-78: brief history - list of amendments to date and where to find them. http://www.imo.org/en/KnowledgeCentre/ ReferencesAndArchives/HistoryofMARPOL/Documents/ MARPOL\%2073-78\%20Brief\%20History\%20-\%20List\%20 of $\% 20$ amendments\%20and\%20how\%20to\%20find $\% 20$ them.htm. (Accessed 04 January 2018) 
19. IMO, 2019. Energy efficiency measures. http://www.imo. org/en/OurWork/Environment/PollutionPrevention/ AirPollution/Pages/Technical-and-Operational-Measures. aspx. (Accessed 13 March 2019)

20. International Gas Union, 2015 . World LNG report-2015 edition. http://www.igu.org/sites/default/files/node-page-field_file/ IGUWorld\% 20LNG\%20Report-2015\%20Edition.pdf. (Accessed 14 November 2017)

21. International Renewable Energy Agency, 2012. Wind power. https://www.irena.org/DocumentDownloads/Publications/ RE_Technologies_Cost_Analysis-WIND_POWER.pdf. (Accessed 11 November 2017)

22. Jafarzadeh, S., Utne, I.B., 2014. A framework to bridge the energy efficiency gap in shipping. Energy 69(2014), 603-612. https://doi.org/10.1016/j.energy.2014.03.056.

23. Johnson, H., Andersson, K., 2011. The energy efficiency gap in shipping: barriers to improvement. Paper presented at International Association of Maritime Economists (IAME) 2011 Annual Conference, Santiago de Chile.

24. Johnson, H., Johansson, M., Andersson, K., 2014. Barriers to improving energy efficiency in short sea shipping: an action research case study. Journal of Cleaner Production 66(2014), 317-327. https://doi.org/10.1016/j.jclepro.2013.10.046.

25. Karvonen, M., Kapoor, R., Uusitalo, A., Ojanen, V., 2016. Technology competition in the internal combustion engine waste heat recovery: A patent landscape analysis. J. Clean. Prod. 112, 3735-3743. https://doi.org/10.1016/j. jclepro.2015.06.031.

26. Klemick, H., Wolverton, A., 2013. Energy-efficiency gap. In Encyclopedia of Energy, Natural Resource, and Environmental Economics, ed. Jason Shogren, 74-81.

27. Kristensen, H.O., 2012. Energy demand and exhaust gas emissions of marine engines. Clean Shipping Currents, $1(6), 18-26$.

28. Larsen, U., Pierobon, L., Haglind, F., Gabrielii, C., 2013. Design and optimisation of organic Rankine cycles for waste heat recovery in marine applications using the principles of natural selection. Energy 55, 803-812. https://doi.org/10.1016/j.energy.2013.03.021.

29. Lele, A., Rao, K.V.S. 2016. Ship propulsion strategies by using wind energy. In 2016 International Conference on Emerging Technological Trends (ICETT) (pp. 1-6). IEEE. https://doi.org/10.1109/ICETT.2016.7873693
30. Marine Pollution Annex VI 2018 EEDI and SEEMP https:// www.marpol-annex-vi.com/eedi-seemp/(Accessed 19 February 2019)

31. Manrique, R., Vásquez, D., Vallejo, G., Chejne F., Amell, A.A., Herrera, B., 2018. Analysis of barriers to the implementation of energy efficiency actions in the production of ceramics in Colombia. Energy 143(2018), 575-584. https://doi.org/10.1016/j.energy.2017.11.023.

32. Mickwitz, P., Hyvättinen, H., Kivimaa, P., 2008. The role of policy instruments in the innovation and diffusion of environmentally friendlier technologies: popular claims versus case study experiences. Journal of Cleaner Production 16S1 (2008), 162-170. https://doi.org/10.1016/j.jclepro.2007.10.012.

33. Ministry of Transport, Maritime Affairs and Communications (Ulaştırma, Denizcilik ve Haberleşme Bakanlığı), 2017. 1978 Protokolü ile Değişik, 1973 Tarihli Denizlerin Gemiler Tarafından Kirletilmesinin Önlenmesine Ait Uluslararası Sözleşme (MARPOL 73/78). http://imo.udhb.gov.tr/TR/19Marpol.aspx. (Accessed 05 November 2017).

34. Nehler, T., Rasmussen, J., 2016. How do firms consider nonenergy benefits? empirical findings on energy-efficiency investments in Swedish industry. Journal of Cleaner Production 113(2016), 472-482. https://doi.org/10.1016/j. jclepro.2015.11.070.

35. Pearson, K., 1895. Notes on regression and inheritance in the case of two parents. Proceedings of the Royal Society of London. 58, 240-242.

36. Polzin, F., 2017. Mobilizing private finance for low-carbon innovation - a systematic review of barriers and solutions. Renewable and Sustainable Energy Reviews 77(2017), 525535. http://dx.doi.org/10.1016/j.rser.2017.04.007

37. Poulsen, R.T., Sornn-Friese, H., 2015. Achieving energy efficient ship operations under third party management: How do ship management models influence energy efficiency? Research in Transportation Business \& Management 17(2015), 41-52. https://doi.org/10.1016/j. rtbm.2015.10.001

38. Reddy, B.S., 2003. Overcoming the energy efficiency gap in India's household sector. Energy Policy 31(2003), 1117-1127. https://doi.org/10.1016/S0301-4215(02)00220-3.

39. Rehmatullaa, N., Calleyab, J., Smith, T., 2017. The implementation of technical energy efficiency and $\mathrm{CO} 2$ emission reduction measures in shipping. Ocean Engineering 139(2017) 184-197. http://dx.doi.org/10.1016/j. oceaneng.2017.04.029. 
40. Ruan, Y., Hang, C.C., Wang, Y.M., 2014. Government's role in disruptive innovation and industry emergence: the case of the electric bike in China. Technovation 34(2014), 785796. https://doi.org/10.1016/j.technovation.2014.09.003.

41. Styhre, L., Winnes, H., 2013. Energy efficient shipping between research and implementation. Paper presented at IAME2013 Conference, Marseille, France.

42. Thollander, P., Ottosson, M., 2008. An energy efficient Swedish pulp and paper industry- exploring barriers to and driving forces for cost-effective energy efficiency investments. Energy Efficiency 1(1), 21-34. https://doi.org/10.1007/s12053-007-9001-7.

43. Thomson, P.B., 1997. Evaluating energy efficiency investments: accounting for risk in the discounting process. Energy Policy, 25(12), 989-996. https://doi.org/10.1016/ S0301-4215(97)00125-0.

44. Trianni, A., Cagno, E., 2012. Dealing with barriers to energy efficiency and SMEs: Some empirical evidences. Energy 37(2012), 494-504. http://dx.doi.org/10.1016/j. energy.2011.11.005.

45. Wärtsilä Encyclopedia of Marine Technology, 2017. Direct Water Injection (DWI). https://www.wartsila.com/ encyclopedia/term/direct-water-injection-(dwi). (Accessed 19 December 2017)

46. Ycharts, 2019. Henry hub natural gas spot price chart. https://ycharts.com/indicators/natural_gas_spot_price. (Accessed 12 March 2019)

47. Yoon, B., Shin, J., Lee, S., 2018. Technology assessment model for sustainable development of LNG terminals. J. Clean. Prod. 172, 927-937. https://doi.org/10.1016/j. jclepro.2017.10.187.

\section{CONTACT WITH THE AUTHORS}

Olgun Konur

e-mail: olgun.konur@deu.edu.tr

Murat Bayraktar

e-mail:murat.bayraktar@deu.edu.tr

Murat Pamik

e-mail:murat.pamik@deu.edu.tr

Barıș Kuleyin

e-mail:baris.kuleyin@deu.edu.tr

Mustafa Nuran

e-mail:mustafa.nuran@deu.edu.tr

Dokuz Eylul University

Dokuz Eylül Üniversitesi Denizcilik Fakültesi Tinaztepe Yerleşkesi 35160 Buca IZMIR

35160 İzmir

TURKEY 